AGRICULTURE AND BIOLOGY JOURNAL OF NORTH AMERICA

ISSN Print: 2151-7517, ISSN Online: 2151-7525, doi:10.5251/abjna.2012.3.4.175.191

(C) 2012, ScienceHuß, http://www.scihub.org/ABJNA

\title{
Fruit thinning with specific reference to citrus species : A review
}

\section{George Ouma}

\author{
School of Food Security, Agriculture and Biodiversity, Bondo University College, \\ P.O. BOX 210-40601 Bondo, Kenya \\ E-mail:goumaoindo@yahoo.com \\ ABSTRACT
}

\begin{abstract}
Fruit thinning is defined as the removal of certain flowers or clusters of flowers or individual fruitlets after fruit set and natural dropping have occurred.it improves fruit yield and quality and return bloom for the following year.There are three types of thinning namely:hand, mechanical and chemical.Chemical thinning is the most common type of thinning.Various chemicals are used for thinning. Still many more are being introduced into the market and they have varying effects on fruit quality and yield,depending on the fruit species and cultivar in question. The effects of these chemicals on fruit set is affected by environmental and ecological factors among other crop factors such as vigour.Alot of research has been conducted or is being conducted on chemical thinning but varied results are generated due to many chemicals being released by the chemical companies and varying farmer situations,yet this topic is of immence interest to chemical companies,researchers ,farmers and the fruit industry. This paper discusses the various factors involved in fruit thinning but mainly the physiological principles behind the process of fruit thinning.A lot of research on thinning has been conducted on Apples and other temperate fruits but not on other fruits such as citrus which has worldwide significance. This review will mainly help pomologists who are conducting research on this area.
\end{abstract}

Key words:fruit,thinning,chemical,chemicals, yield,quality, return bloom,physiological

\section{INTRODUCTION}

Thinning can be defined as the removal of certain flowers or clusters of flowers or Individual fruits after fruit set and natural dropping has occurred (Valenzuela, 1992). Under optimum conditions most trees will set more fruit than needed for a full crop. Fruit thinning is carried out to reduce limb breakage ,increase fruit size, improve colour and quality and stimulate floral initiation for next year's crop. (Westwood, 1993). When the leaf to fruit ratio is increased by removing some of the fruit remaining become larger but not in direct proportion to the increase in the number of leaves per fruit, causing yield reduction. There are three general methods of thinning namely; hand, mechanical and chemical. Hand thinning is removing flowers or fruit. Previously, fruits were thinned to a predetermined spacing but now size thinning is preferred. (Westwood, 1993). Size thinning is selective removal of small, weak fruit irrespective of spacing with the consideration of the desired degree of thinning. Mechanical thinning may be carried out in three ways; the first way is the use of a direct blast of high pressure water from a hand operated sprayer at or slightly past bloom. A second way is to use a stiff bristled brush to "sweep' off some of the fruits while they are still small. A third way uses a power tree shaker of the type used for mechanical harvest. The force causes the heavier fruits and those closer to the point of impact to separate from the spurs.

(Byers, 1990, cited by Valenzuela, 1992) Blossoms or fruits can be thinned. In practice early fruit thinning (from bloom upto about 2 weeks before pit hardening) can reduce the percentage of small peach fruit at harvest (Farley, 1923; Shoemaker, 1933), ilncrease total yields (Havis, 1962) and advance maturity. (Havis, 1962) by reducing interfruit competition for scarce resources. Chemical thinning at bloom may reduce the risk of foliage damage by caustic materials in varieties where leaves emerge after flowers and uneven absorption or transport through leaves which may cause erratic

results. The advantage of thinning blossoms rather than developing fruit is that it maximizes the ability to adjust the fruit - to - leaf ratio; a method which hastens ripening in peach cultivars with short development period and fruit sizing problems, (Byers and Lyons, 1983; Havis, 1962). The assumption made for this method is that fruit set will be in excess of that needed for a satisfactory crop and reduced June drop. (Shoemaker, 1933). may reduce the 
dangers of poor set or frost near to bloom. The type of chemical thinners used to thin fruits are mainly Accel (Ouma, 1996), CPPU (a cytokinin) - Bound et al. 1991; Ethephon ( Elfving, 1984), gibberellins (CA 3) (Valenzuela, 1992); Benzyladenine (A cytokinin) (Elfving, 1989, Oxamyl.

(Vydate -21) Marini, 1997), Carbaryl, (Ouma, 1996) and others. In peaches flower and fruit thinning are essential commercial practices to optimize fruit size,maximize crop value,improve fruit clour,shape and quality,promote return bloom and to maintain tree growth and structure. Hand thinning fruitlets at 45-50 days is the standard commercial practice in most peach producing areas.Hand thinning of peaches is the single most expensive management practice of growing peaches. However, there are a lot of incentives for growers to reduce crop load to increase fruit size since large fruit is usually more valuable than small fruit in the fresh market.Chemical thinning in peaches has the potential to be superior to hand thinning but it is uncommon in commercial orchards because it is risky and produces poor results due to the risk of overthinning.( Osborne and Robinson,2008).This is particularly so with bloom thinning which must be done very early in the season before the grower can judge crop size or market conditions and before the danger of frost has expired.

In some countries Nitrogen fertilizers such as Urea, Calcium nitrate, Ammonium thiosulphate (ATS) and Azolon fluid )(Methyl Urea solution) are used as thinners. These chemicals are applied as blossom thinners and their mode of thinning are apparently scorching of blossoms and leaves and ethylene synthesis. (Hand chack, 1994). This effect is particularly evident with urea and calcium nitrate (Zimmer et al. 1996) The thinning afficacy depends on the degree of leaf and blossom scorching from the higher treatment concentration and spray volume. Therefore application of urea and calcium nitrate has to be limited to the prebloom stage. Azolon fluid can be applied during full bloom stage.ATS has thinned peaches satisfactorily when applied at full bloom at $5 \%$ but it overthinned. (Osborne and Robinson,2008)

Although these chemical have limited thinning effect they promote fruit size, colour and firmness.

Mode of Action of Chemical Thinners: From a lot of research previously conducted to determine the mechanism of action of thinners,. It is generally believed that some thinners temporarily delay abscission of young fruit. Delay in natural abscission increased competition for nutrients which reduces the numbers of fruit after "June Drop" (Teubner nad Murneck, 1955). This theory has not been universally accepted particularly for Naphthalein Acetic Acid (NAA) because it thins moderately to heavy without delaying fruit drop. (Williams, 1979). The other mode of action which is possible is via phloem transport of hormones and photosynthates in and out of fruits. There is usually an auxin gradient between a leaf or fruit and the spur delays the formation of an abscission layer. After their application, synthetic auxins stop and or reverse the auxin flow and induces fruit drop.

(Crane, 1969). The other possible mode of action especially by NAA is ethylene evolution. (Walsh, et al. 1979). This is clearly demonstrated from the fact that the thinning effect of NAA can be cancelled by treatment with Amino ethoxyvinyliene (AVG) which is an inhibitor of ethylene evolution. (Williams, 1987).

Carbaryl's mode of action has been reported to be due to its effect on fruit or fruit abscission. (Westwood and Batjer, 1960). This is due to the fact that it affects fruits or fruit let abscission. Fruit from trees treated with carbaryl had fewer seeds. Fruitlet abortion either occurs by carbaryl interfering with the influx of metabolites by direct influence from within the vascular system causing reduced growth and eventual abscission (William and Batjer, 1964) or by carbaryl stimulating the activity if existing sinks, which increases competition and reduced metabolite flow into the fruit lets. (Knight, 1963).

Cytokinins cause thinning of fruits by reducing energy available for developing fruit by reducing net $\mathrm{CO}_{2}$ assimilation rate. They also reduce fruit set by promoting fruit abscission. Cytokinis increase fruit size in apples but in the absence of thinning they also increase fruit size Cytokinins promote cell division in apple tissue.

(Letham, 1958) and cell division is still under way in fruits when BA, a cytokinin is applied for thinning (Denne, 1963a, 1963b, Schechter et al. 1993a, 1993b). These reports have led to the hypothesis that BA used as a thinner may affect the rate or duration of cell division in the apple fruit hence increase cell and fruit size.

Gibbarellins act by inhibiting flower initiation in apples, pear and grapes. Flower inhibition causes reduced seed numbers. The seedlessness which is caused by Gibberellins is due to its injuries on the ovules. (Valenzuela, 1992). 
However, application of gibberellins to pear trees improve fruit size and fruit weight without affecting yield showing that there is competition at a very early stage before effects of midseason fruit let shedding which may affect cell division more than cell expansion. There are definitely physiological principles involved in fruit thinning. The formation of abscission layers and consequent fruit drop has been due to the combined action of auxins (Moore, 1984) and ethylene (Bangerth, 2000; Smith and Hall, 1993, Brown, 1997). This is why auxin analogues such as NAA are used for these purposes. (Schonherr et al. 2000; Stopar et al. 1997), either alone or in combination with other fruit thinning agents which affect the endogenous auxin levels in the plant directly, such as 'Ethrel' (2-chlorophosphoric acid). (Brown, 1997). When the auxin Naphthalein Acetamide $\left(N A A_{m}\right)$ was used as fruit thinning agent at $100 \mathrm{ppm}$ on apples epinasty and phytotoxicity was reported. (Schumacher et al. 1993), Bertzchinger et al. 1999 on CV Gala apples and and CV 'Golden Delicious' apples. In the latter apples variety it reduced leaf and shoot growth (Schumacher et al. 1993) while it induced leaf yellowing and curvature in CV 'Gala (Bertschinger, 1998).

The effect of fruit thinning on physiological processes such as photosynthesis and respiration has been scarce and centradictory. (Bangerth and Quinlan, 2000; Stopar et al. 1997). However research conducted by Untiedt and Blanke, 2001) has shed some light on this issue. These people investigated the effects of the thinning agents on photosynthesis. They used Naphthalein acetic acid (NAA), (Rhodofix) and Naphthalein acetamide ('Amidthin' and 2-chloro phosphoric acid ('Ethrel') These chemicals were evaluated on the stress they cause to the fruit tree. The alternate bearing sensitive apple cultivar, 'Elstar' was used for the study. The hypothesis used for this study was that plant stress in the form of large reductions in leaf photosynthesis are a prerequisite for successful fruit thinning. The results showed that all the employed thinning agents reduced whole tree photosynthesis consistently by $3-34 \%$ on the five days following their application with photosynthesis still declining thereafter, in the case of the NAA and 'Amidthin' application. The reduction after application for either 'Rhodofix' or Ethrel' reduced within five days. restoring most of the photosynthetic' potential and showing acceptable phytotoxity of these plant growth regulators at the concentration used.

The effects on dark respiration were differing with NAA and 'Ethrel'. increasing dark respiration by up to
$106 \%$, whereas 'Amidthin' and Rhodofix, decreased it up to $46 \%$ in the first night after application thereby seriously affecting the carbon balance of the tree in opposite ways. These results could be hypothesized as follows, linking basipetal auxin transport, phloem loading, translocation and deficiency of photo assimilates as shown below;

$$
\begin{aligned}
& \text { Leaf photosynthesis } \\
& \text { and darktrespiration } \\
& \text { Photo astimilates } \\
& \text { Phloem } \\
& \text { Leaf to ading } \\
& \text { Sink strungth } \\
& \text { Of fruit tets } \\
& \text { Ethylentocation biosynthesis } \\
& \text { Auxin stnthesis } \\
& \text { Basipetal auxin transport } \\
& \text { Separdte zone } \\
& \text { Fruit thlinning } \\
& \text { (Untiedt and Blanke, 201) }
\end{aligned}
$$

With all fruit thinning agents applied, the reduction in whole tree canopy photosynthesis was consistent which implies a possible joint mechanism for the mode of action of the plant growth regulator -induced photoassimilate deficiency. (Stopar et al. 1997) due to reduced mesophyll conductance curtailing translocation from the leaf to the fruit let (Schneider, 1978). This inhibition of tree photosynthesis most probably causes a short and vigorous stress at a time when foliage is limiting and the juvenile leaves are still developing. This could also explain the reported phytotoxity of NAA (m) (Bertschinger et al. 1999, Schumacher et al. 1993), since these thinning agents caused the largest reduction in tree photosynthesis which increased after the five days.

In biochemical terms, the combination of reduced basipetal auxin transport and photoassimilate deficiency increased the activities of pectinase and cutinase enzymes in the abscission layer. During the same time the abcissioning fruit is retarded in growth and releases more stress ethylene (Ouma, 2010).

Fruit Abscission: Abscission is the process of shedding plant organs such as leaves, flowers, or fruits. Abscission of fruits may consist of differentiation of discrete abscission zone through 
separation (Janick, 1979). Abscission is preceded by senescence and mature fruits are separated from the tree when leaves, flowers or fruits reach the end of the life cycle or mature.

Abscission is caused by changes in daylength or temperature in preparation for winter. Part of the full crop or the plant may be dropped throughout the period of the fruit growth and development. The time of fruit retention can also be influenced by removal of competing fruits and application of chemicals. Plant growth regulator can be applied to prevent preharvest abscission of apples (Malus) and pears (Pyrus), delay petal abscission in flowering cherry (Prunus) and reduce young fruit abscission in tomatoes (Lycopersicon) (Janick, 1979).Auxins retard abscission therefore they are used to prevent preharvest drop or abscission.

Fruit abscission generally occurs simultaneously with maturation and ripening although in some species it occurs immediately after pollination and fruit set.Inherent patterns of reproductive growth also cause abscission. These patterns cause pronounced annual variations in immature shedding of reproductive structures which cause big losses to Citrus and apple growers( Ouma,2010)..At maturity fruits abscise either with seeds enclosed e.g indehiscent fruits or after release of seeds,e.g dehiscent fruits.Abscission layer varies in different fruits,from pedicels in pome fruits,fruit stalks in plums,base of the fruit in cherries,beneath the ovary in citrus( Esau,1976) In Apples the separation layer of mature fruits has cells in several tiers which increase in size,their secondary walls in sclerechyma lose their anistropic qualities,their middle lamella,primary walls and much of their secondary wall thickening dissolves while vessels and fibres rupture.The abscission layer of citrus has a lot of starch in it while pectin disappears and the cell walls weaken causing preharvest abscission(Ouma,2010) The abscission layer of sour cherry( Prunus cerasus) is formed between the fruit and the pedicel 12-15 days before fruit maturity. Its process of abscission entails cells separating without rupture of walls but later collapse.In sweet cherry(Prunus avium)there is no definite abscission layer at the base of the fruit.( Esau,1976).

The formation of abscission zone comprises an ordinary sequence of anatomical and physiological changes leading to cytolysis.Because the weakening cells of the abscission zone can no longer support the subtending plant it abscises from its own weight or due to some external force( Esau,1976).Structural changes during abscission are of two types namely detachment of the fruit from the plant and protection of the surface area exposed on the plant after fruit fall.The scar left after the fruit falls is healed by the periderm and lignin is deposited in the region near to the fruit.( Ouma,2010).

The composition of the abscission zone comprises calcium oxalate crystals.Mature fruit abscission comprises cell divisions which occur during the formation of protective zone.In many fruits a periderm or protective zone is formed during their abscission. The periderm is formed at the base of the fruit stalk,where it joins the leafy twig as in mango fruit.At the periderm the composition of the mango fruit consists of lignin and suberin in the parenchyma cells and tannins and tyloses in the xylem.(Janick,1979).The detachment of fruits encompasses the formation of anatomically distinct separation layer which facilitates abscission.Subsequently, the actual separation of the adjacent cells from the chemical alterations in the cell walls occurs.( Ouma,2010).The commencement of cell separation varies in many fruits.In sour cherry it starts at the central portion of the abscission zone above the stony pericarp and moves toward the periphery while in apple fruit it starts at the epidermis at the base of the pedicel and moves through collenchyma vascular tissue and parenchyma cells of the pith.(Janick,1979).Similarly,the ultimate degree of separation varies in many fruits depending on mechanical resistance.For example,in sour cherry fruit separation is affected by mechanical fracturing of the vascular strands through which the differentiated abscission zone does not reach.In musk melons separation is from the vine after collapse of vascular cells.(Esau,1976)Fruit abscission occurs by the cell wall changes which cause separation of cells comprising the hydrolysis or dissolution of the middle lamella which causes the loss of cementing effectiveness between the adjacent cell wall.( Ouma,2010).Subsequently, there is dissolution of lamella and breakdown of all or parts of the cellulose cell wall and lastly mechanical breakage of nonliving elements.

Studies have been conducted to investigate the efficiency of fruit removal by harvesting machines which shake trees. With respect to the above, it was reported that the efficiency of cherry fruit removal depended on the effect of growth substances on cherry abscission.

The abscission process is also influenced by ethylene and abscissic acid.It showed that in the 
early stages this force of fruit removal increased in relation to the tissue differentiation in stalk and the fruit but when separation layer is formed as a result of this development the fruit removal force decreases.( Esau,1976)When this time is reached the fruit becomes sensitive to exogenous ethylene application which reduces resistance to breaking.

Biochemically, the enzymes in the abscission zones are dehydrogenases, acid phosphatases. The activities of peroxidases are high at the junction of the receptacle and fruit tissue.Additionally,there is also synthesis of proteins and RNA in the abscission zone.This was proved by applying cyclohexamide,an inhibitor of RNA and protein synthesis and abscission was delayed.( Goren,1993)

It can therefore be concluded that the synthesis of RNA and protein can be a direct cause of abscission and may be a requirement for synthesis of wall degrading enzymes such as cellulose.The process of separation is facilitated by ethylene and abscissic Acid.The role of plant growth regulators are variously to encourage drop of fruitlets to thin fruit in cultivars with low fruit production, to loosen fruit for easening of mechanical harvest and prevent preharvest drop.(Goren,1993)

Some plant growth regulators such as ethylene cause fruit and leaf abscission. This is economically disadvantageous. Future research should be directed at developing substances which cause fruit drop without leaf drop.(Ouma,2010)

Other factors which affect fruit abscission are age, type of fruit trees, amount of bloom, weather, stage of development of the fruit and practices such as shading (Ouma, 2010; Stuttle and Goge, 1990), removal of spur and shoot leaves and ringing. (Ferree and Palmer, 1982) ,tree vigour,fruits borne in clusters( Ouma,2010)

Brief cool temperatures before applications soften the leaf cuticle while frost may weaken flower parts,reduce pollen tube growth and fertilization and promote fruitlet abscission.Wet or damp weather at the time of application or immediately after will extend the dryness of the leaves and increase chemical absorption. High relative humidity will increase the uptake of the chemicals and so will after cool periods by causing tree stress and increasing the reaction of chemical thinners.

Trees with heavy crop load the previous year are more easily thinned.Similarly trees with heavy blooms are more easily thinned as compared to those with light blooms.( Janick,1979)

Stage of development also affects fruit abscission.In peach for example,there are three stages of development namely stage I(characterized by rapid growth of the pericarp and limited embryonic development,Stagell ( characterized by rapid development of embryo and hardening of the endocarp and Stagelll (rapid mesocarp expansion)( Gore,1990). Cultivars differ in the length of each phase,with early and late cultivars differing mainly in the duration of each stage or phase.Early and late season cultivars differ in the duration of stage II (Stuttle and Goge,1990).A lot of physiological ,biochemical and morphological changes occur during early seed development(stage I) (Zuchini,1983).Abscission of peach varies from late stagel (Crane,1963),"June drop"fruits(stage(onset of stagell)(Turkey,1936) cited by Stuttle and Goge,1990 who observed that the killing of embryo during early stage II or III caused fruit abscission in several peach cultivars.Some practices also affect fruit abscission.Shading the fruit trees cause abscission Byers et al.(1990) investigated the effect of different levels of shading on red delicious apple trees for 10 day periods from 10 to 20,15 to 25,20 to 30 and 25 to 35 days after full bloom. He reported that this interval caused greater fruit abscission than shading from 5 to 15,30 to 40,35 to 45 to 57 days after full bloom. Fruits of diameter 8 to $33 \mathrm{~mm}$ in diameter(10 to 30 days after full bloom) were very sensitive to 10 days of shade but fruit sizes of 6 to $12 \mathrm{~mm}$ are usually the most sensitive to chemical thinners.Shading fruit tree limbs by spraying trees with chemical photosynthetic inhibitors can induce abortion as has been reported in apple and apple(Byers et al. ,1984,1985). The explanations of these findings are that a brief period after bloom when the fruits are extremely sensitive to the application of a photosynthetic inhibitor or light limitation by shading treatment.Similarly, it has been reported that shading whole trees is more effective than shading limbs on old trees(Byers et al.,1985) Chemical thinners also cause fruit abscission which causes thinning.Similarly,photosynthetic inhibitors can also be applied as thinners.Byers et al.,1990).Apple fruit abscission after fertilization and during June drop is considered to be caused by the competition for essential metabolites among individual fruitlets and vegetative shoots. (Quinlan and Preston, 1971) It has been reported that NAA thinning sprays reduced the amount of reducing sugars in young apple fruitlets(Schneider and Lasheen,1973) 
.This is apparently due to reduced level of photosynthates reaching the developing fruit.Further reports have indicated that the most sensitive period for NAA( Naphthalene Acetic Acid) induced abscission in apples is 10 to 20 days after full bloom.It has been observed that chemical photosynthetic inhibitor activity and natural June drop are initiated at about the same critical period as hormone spray thinning.(Ouma,2010).Shade thinning is apparently effective for a longer period than chemical thinners. The mechanism causing June drop or NAA,Carbaryl or ethylene induced abscission may be similar to that caused by photosynthetic inhibitors though age of the leaves may limit their effect later in the season.( Byers et al.,1990)

Time of Application of Chemical Thinners: Timing of application of chemical thinners can be affected by many factors including species or cultivars.Application can be timed by calendar reference to a particular stage of blossoms.But this method is not recommended because it does not consider year-to-year variation nor any side effect on fruitlet growth and the role that this may have in response to a chemical thinner.(Knight,1987).Another method used is by timing according to size which is also not possible practically because fruit bloom over an extended period and sprays cannot be applied when fruits are of a certain size.(Janick,1979)Differences in tree and spur vigour also affect growth rate and therefore fruit sizes on any given tree or among trees can vary a lot..The timing of sprays based on day after full bloom has been observed to be both satisfactory and practical. This will also reduce the risk of overthinning during spraying of large blocks of land.Such growers should start spraying at the earliest recommended date.In years with very warm or cool periods before thinning the time of application should be adjusted according to the stage of plant development.(Ouma,2010)Warm temperatures fasten growth therefore thinning sprays should be applied earlier.Bloom is spread over several days in many apple growing areas and postbloom growth is delayed by weather.Fruit size may be used as aguide for same type of fruit.

With postbloom sprays the effective thinning period is from one to two weeks or more varying with weather.The effect of adverse weather occurring after spraying would be reduced by spreading chemical application over the effective thinning period.In a study to find the effect of time of application of $\mathrm{GA}_{4+7}$ on fruit set,fruit quality and return bloom of Mcintosh and 'Empire' apples it was observed that flower bud formation was inhibited on 'Mcintosh' when $\mathrm{GA}_{4+7}$ was applied over a wide range of times from 6 days before full bloom to 34 to 35 days after full bloom.Applications which were made after full bloom had no effect.(Greene,1989). Fruit size influences the effect of Accel on the thinning response of 'Gala'apples as reported by Hull et al.,1995..The apple trees were treated at the size of 5 to $20 \mathrm{~mm}$ with 10 grams per acre of Accel.Early application of Accel sprays when the fruit was $5 \mathrm{~mm}$ in size was more effective than late application when the fruit was $10-20 \mathrm{~mm}$.NAA and Carbaryl are also applied to thin apples.Usually,they are applied when the largest fruits are 4 to $15 \mathrm{~mm}$ in diameter.When sprays are applied at the larger diameter of $10-15 \mathrm{~mm}$ the warm weather after spraying is advantageous because it increases stress and maximizes reduction of fruit set with a minimal effect on the seed number.But when the temperature is cold seed abortion occurs.( Williams,1993 ;Marini,1996)The amount of chemical absorbed is dependent on the type and amount of surfactant,whether ionic or non-ionic.It has been reported that foliar penetration of amitriazole is influenced more by the chemical nature of the surfactant added than by the reduction of surface tension.Although surface tension reduction and surface wetness are important the molecular interaction of surfactant and chemical thinner is of equal or greater importance. This was reported by Freed and Montgomery(1958) on herbicides.Westwood and Batjer,1960 reported that successive increases in NAA absorption as the concentration of surfactant was increased were far beyond that required for minimum surface tension.

Methods of Application of Thinners: Variation of tree vigour and fruit set patterns necessitates a selective method of spray application. Dilute sprays applied with high pressure hand gun give best results. This method uses individual limbs or heavily loaded areas of the tree can be treated selectively without affecting the areas that require little or no thinning.In parts of the orchard which have fairly uniform fruit set and tree vigor a hand gun can be used during the thinning period if there is a problem of inability to cover the entire acreage.( Ouma,2010).Overthinning can be prevented by turning the lower spray jets.

When applying insecticides and growth regulators and chemical thinners concentrate sprayers are used. Good thinning results have been produced by applications of 750 to 1000 litres per hectare of thinning agents ( Williams,1979).Delicious apples are unaffected by the concentration of the sprays. 
The degree of abscission is affected by the amount of chemical absorbed by the foliage and absorption is affected by the volume and concentration of the spray solution.Maximum absorption occurs when the leaves are wet.When the volume of water is reduced to 940 litres per hectare from 2800 litres per hectare which is a dilute rate the drying time is reduced and the absorption potential is also reduced proportionately.(Ouma,2010) Consequently, when the volume of water is small,the solution must be of high chemical concentration to compensate for the short drying time to eliminate the low thinning effectiveness and chemical absorption which results. ( Williams, 1979)The choice between concentrated and dilute solutions of thinning chemicals requires an experience of 3 to 5 years to compare thinning results.Dilute applications need more time for filling and mixing but it results in improved quality and return bloom...Chemicals which can cause excessive foliage damage and seriously overthin particularly if cool damp conditions prevail after application should be applied as dilute sprays.( Ouma,2010)

Necessity of hand thinning after chemical thinning: Hand thinning should be delayed until 50 to 60 days from bloom when the small fruit can be differentiated easily from the large fruit. The vigour and general condition of the tree should determine the amount of fruit left on a tree.

The potential fruit size at harvest should determine final hand thinning and this should be predicted to be at 50 to 70 days. Harvest size can be predicted by a fruit size prediction chart.(Batjer et al.,1957)

Hand thinning by fruit size removes a high percentage of the smaller, seedless fruit and low seed count fruit.For tree cultivars with parthenocarpic fruit set postbloom thinners cause seed abortion therefore the small, low seed count fruit should be removed during the follow-up hand thinning operation.Excessive hand thinning ,which is costly should be avoided.(Williams, 1979)

\section{EFFECTS OF FRUIT THINNING}

Effects of fruit thinning on fruit size and yield: It has been reported that fruit thinning increases yield in various apple cultivars.(Greene and Autio,1990) found that Benzyladenine(BA) increased fruit size as a result of increased cell division on several apple cultivars.Other workers namely,Elfving,1989 on 'Idared' apples using BA at $100 \mathrm{ppm}$, Greene et al.,1990 on 'McIntosh',Delicious',Golden Delicious and 'Empire' apples using a combination of NAA at $7.5 \mathrm{ppm}$ and Carbaryl at $600 \mathrm{ppm}$.Carbaryl alone also increased the fruit size of 'Empire' apples(Wismer and Proctor,1995).Large fruits have more cells but not larger cells than small fruits from the same tree.Similarly,fruit from light cropping trees in all cases have larger cells than do small fruit from heavy cropping trees.( Ouma,2010).Chemical thinning usually causes more cells per fruit.Chemical thinning after cell division period led to fruits with more cells than hand thinned fruit showing that the chemicals selectively remove the small,weak fruits(Westwood,1993).It has been reported that unselective early hand thinning resulted,nonetheless in larger fruit mainly from larger cells.(Westwood,1993). The number of cells in fruits is also affected by position of the fruits.For example,centre bloom fruit(i.e those from the terminal flower of the inflorescence) of 'Delicious' apples had larger but no more cells than side bloom fruit(Westwood,1993).Conversely, those of 'Golden Delicious' had both more and larger cells than side bloom fruit.(Ouma,2010). Time of thinning also affects the number of cells and it has been reported that early hand thinned 'Delicious' apple fruit thinned 1 week after full bloom had slightly more cells and larger fruit than did late,light thinning.(Ouma,2010).Cell number is increased by chemical thinning of 'Golden Delicious' and to larger extent than can be explained for by the degree of thinning. Applying NAA and Carbaryl 18 days after bloom resulted in their thinning action not completed until after cell division ceased.Chemical thinners are therefore so selective in their actions(i.e they selectively remove the weak, small fruit that contain fewer cells). This explains why random hand thinning is not as effective in fruit sizing.( Westwood,1993) Many workers such as Elfving and Cline,1993 using BA on apples,Stiles(1995) using Carbaryl and NAA and Marini,1996 on apples using NAA have reported that chemical thinning generally increases fruit size.When fruit size or weight was not affected by chemical thinners, it was concluded that they were applied after cell division had occurred.(Ouma,2010).

Effect of Chemical Thinners on Fruit Shape: Fruit shape is best expressed by the ratio of its lenghth to diameter.This is a very important economic parameter and it facilitates the comparison of shapes of very small fruit in early season with larger ones later on.It is similarly called relative fruit length. The bigger the ratio the more elongated the fruit.As the fruits commence growth the ratio decreases and finally levels off before harvest. One of the factors which increase fruit length is heavy thinning or light bloom which causes a light crop and centre position 
rather than side position on the cluster. Fruit shape is affected differently by chemical thinners. While some thinners increase fruit elongation(some cytokinins,(William and Stahly,1969),gibberellins and cytokinins(Westwood,1993), reduce

fruit elongation(2,4-diphenoxyacetic acid), and no effect on fruit lenghth(Kinetin and Indole acetic acid (Elfving and Cline,1993).

Hand thinning at various times between bloom and harvest, however causes more fruit elongation than controls. Similarly, fruit trees thinned early are more elongated and larger than those thinned at 60 or 90 days after full bloom. (Westwood,1993).

Effect of Chemical Thinners on Seed Number: There have been reports that there exists a linkage between chemical thinner sprays that influence seed number and fruit storage potential. Sprays containing GA increase seedlessness in 'Mclntosh'apples and these seedless fruits are prone to senescent breakdown( Greene et al.,1982 cited by Greene,1989.Conversely,it has been reported that bloom or post bloom sprays which contain $\mathrm{GA}_{3}$ produce parthenocarpic fruit with fewer seeds(Greene,1989) that are also low in calcium.A direct and inverse relationship has been reported between fruit $\mathrm{Ca}$ and seed number.(Weis et al.,1985 cited by Greene,1989.Seed produced auxin has been linked with reduced levels of $\mathrm{Ca}$ because auxins, usually produced by seeds would be present in small amounts.(Greene,1989).Different chemical thinners have had varying effects on the number of seeds ranging from no effect, reduced and increased effect.

Effects of Chemical Thinners on the Colour of fruits: Different consumers from different parts of the world have different fruit colour preferences which varies with local customs and the main varieties grown.Generally,highly coloured fruit from a normaly red variety are usually of better quality than poorly coloured ones from the same tree.Red,blue or purple colour of fruits is caused by the synthesis of anthocyanin pigments as they mature and this is affected by light. Red pigmentation in fruits is affected by cultural and environmental factors such as pruning,thinning,fertilization,temperature and light.Factors that increase the level of carbohydrates before harvest usually increase anthocyanin pigment.Factors such as pruning,tillage, fruit thinning,fertilizer application and pest control affect fruit colour due to their probable effect on the effective leaf area, leaf to fruit ratio, carbohydrate level and the amount of fruit shading before harvest .A close relationship has been reported between leaf to fruit ratio, sugar content and red colour of 'Delicious' apple. Fruit with a low sugar content and low leaf to fruit ratio had poor colour development even when exposed to optimum sunlight.( Magness,1929) cited by Westwood,1993.It has been reported that apples developed the best colour when fruits and leaves were exposed to $70 \%$ full sun.(Heinecke,1964). He reported that below $40 \%$ full sun, fruit colour was inadequate and was adequate at $40-70 \%$ full sun. He also reported direct correlation between soluble solids and light exposure. Chemical thinners advance fruit maturity when they increase soluble solids.(Ouma,2010).

Effect of Chemical Thinners on Sugar content and $\mathrm{pH}$ : Chemical thinners affect $\mathrm{pH}$ and sugar content or not. Greene and Autio (1993) reported that increasing sugar content from BA treated apple trees was due to its thinning activity which changed the leaf to fruit ratio so that there were more leaves to support fruit growth. As the sugar content increased the amount of acids decreased thus increasing the fruit $\mathrm{pH}$.

The mineral status of the apple tree has similarly been implicated in the effect of sugar and acidity levels of the fruit.(Marcelle,1995) who reported that $N$ content was negatively correlated to fruit $\mathrm{P}$ content and acidity. He also reported that sugar content is negatively correlated to fruit $\mathrm{P}$ content in 'Sungold' apples and a positive correlation between fruit $\mathrm{K}$ content, acidity and sugar contents.

Effect of Chemical Thinners on Biennial Bearing: Irregular bearing is a characteristic of many trees and this affects cropping uncertainty and overall reduction in yield.It usually encompasses a heavy crop one year followed by a light yield the following year.Consequently, heavy and light yields from "on" and 'off'crops are associated with biennial bearing.(Janick,1990).

A part from the reduction in fruit numbers a heavy crop reduces the number of cells in the cortical tissue of the developing flowers for the following year's crop causing smaller fruit in the 'off' year.(Ouma,2010).Trees usually bear on alternate year due to the excessive fruit set during the "on" year.Fruit bud formation is reduced or completely prevented when the quantity of fruits in relation to the amount of foliage is excessive. Many fruit tree cultivars have biennial bearing and even cultivars with regular bearing should be thinned early to reduce biennial bearing tendency.(Janick,1990) 
Chemical thinners reduce fruit set relatively early in the growing season and the tree forms more fruit buds for the next year's crop.The amount of bloom for the following year is affected by the date of thinning whether by hand or chemicals.Because of this relationship and the large amount of labour required for proper thinning early chemical thinning is needed for annual bearing of fruits.(Ouma,2010,Janick,1990,Westwood,1993).

Effect of Chemical Thinners on Leaf and Fruit Mineral Composition: The effect of chemical thinners on foliar nutrient composition is usually an indicator of crop load induced changes on foliar levels of mineral nutrients,.increase in one mineral element from reduced fruit load can reduce levels of other mineral elements.(Ouma,2010).When chemical thinners affect shoot growth it may have an effect on foliar nutrient composition( Elfving and Cline,1993).BA has been reported to increase shoot growth which caused changes in mineral composition with respect to $\mathrm{K}, \mathrm{Ca}$ and $\mathrm{Mg}$.Nevertheless,foliar mineral nutrient composition is affected by several other factors such as soil fertility and environmental factors during spraying which affect the activities of the chemical thinners.Different tree cultivars and rootstocks also act differently in response to chemical thinners and this may affect the mineral nutrient composition.(Ouma,2010).Chemical thinners are classified according to having direct and indirect effects. Their direct effects occurs through reducing the basipetal movement of auxin which reduces the acropetal movement of $\mathrm{Ca}$ and other mineral elements resulting in the reduction of $\mathrm{Ca}$ mineral content.Conversely, the indirect effects are associated with a change in fruit size,elimination of shoot-fruit competition for nutrients, increase in root mass and elimination of mycorrhizae(Faust and Miller,1989).

Fruit quality substantially depends on its mineral nutrient particularly $\mathrm{Ca}$ and $\mathrm{P}($ Sharples,1980;Bramlage et al.,1974).Ca plays a key role in delaying senescence and its deficiency causes several disorders in apples,pear,peaches and other fruits.(Faust and Shear,1972), $P$ also influences storability of fruit and it also causes internal break down of apple.Fruit storability is also influenced by ratio of $\mathrm{N}$ to $\mathrm{Ca}$ and $\mathrm{K}$ to $\mathrm{Ca}$ and even Mg.(Marcelle,1995).

$\mathrm{Ca}$ uptake by fruit trees is affected by their physiology.(Faust,1986b).Since Chemical thinners and plant growth regulators in general affect tree physiology when they affect $\mathrm{Ca}$ uptake. Direct uptake of $\mathrm{Ca}$ transport may be affected by Indole Acetic
Acid(IAA) transport.(Banuelos,1987). This is demonstrated by spraying an auxin inhibitor on apple trees as early as two weeks after bloom when $\mathrm{Ca}$ accumulation is decreased.(Stahly and Benson,1976).Similar results were observed when paclobutrazol was sprayed on 'Jonathan' apples when $\mathrm{Ca}$ content was reduced by $28.5 \%$ one month after anthesis and to $11 \%$ at maturity.( Kallai, et al.,1987).

The indirect effects of $\mathrm{Ca}$ transport acts in the following ways:

(a)Effects on roots: In this case the supply of carbohydrates to the root assists in Ca uptake by the apple.When carbohydrates are increased root growth is induced and the young unsuberised roots may induce its growth and these will absorb more $\mathrm{Ca}$ through the apoplast.( Ouma,2010)

(b) Fruit size: An inverse curvelinear relationship exists between fruit $\mathrm{Ca}$ and fruit diameter.

(c)Shoot-fruit competition: When there is vigorous and rapid growth of the shoot high amounts of $\mathrm{Ca}$ are transported to the tree especially young leaves and growing points. High cropping trees with low rates of shoot growth provide sufficient minerals to the developing fruit and the limited number of leaves prevent excessive growth of the fruit.In contrast, the competition between fruits and shoots in a lighter cropping tree with a higher rate of growth is substantial.(Curry and Williams,1986). These people also reported that $\mathrm{Ca}$ content of fruit increases as shoot growth is reduced by Paclobutrazol.

To conclude,the direct effect of most plant growth regulators is to reduce $\mathrm{Ca}$ and may be other mineral elements in the fruit while their indirect effect is to increase fruit $\mathrm{Ca}$ content by reducing fruit size,eliminating sinks in the shoot and increase root mass.(Ouma,2010)

\section{THINNING OF CITRUS,}

Introduction: The importance of fruit size as a parameter of quality of citrus fruits has increased substantially in recent times. The consumer market preference for large fruit causes large differences in price between large and small fruit to the point that the income from the smaller fruit is often less than packing and hauling costs. Fruit size has become as important as yield in the determination of the probability of citrus plantings, and an economic premium is usually obtained through increase in fruit size even at the expense of a reduction in crop yield. 
This applies to all fruit sizes of fruit species such as lemons, oranges and grape fruits

To increase fruit size beyond the limits which may be obtained through the optimization of the standard cultural practices (fertilization irrigation, pruning). Several techniques have been tried such as hand thinning. (Falivene and Hardy, 2008), chemical and hormone thinning (Iwaheri, 1978; Azner et al., 1995; El Otmaini et al., 1993) and the hormonal stimulation of fruit growth rate by synthetic auxins (Aznar et al., 1995; Cleland, 1987; Agusti et al. 1995).

Fruit size of Citrus and Chemical fruit thinning: This is an important factor of quality for citrus fresh consumption. Many and varied factors have been reported to control fruits size (Goldmidt and Monselse, 1977; El - Otmani et al. 1995; 2000; Agusti and Almela, 1991;Cuardusl and Garcia - Luis, 2000) . Several techniques have been applied to improve fruit size, namely girdling. (Cohen, 1984), application of fruit thinner agents. (Gallasch, 1988; Agusti et al. 1996) and the application of fruit enhancer substances. (Agustin and Almela, 1991; Agusit et al. 1994, 1995, Aznar et al. 1995; El Otmani et al. 1993).

Synthetic auxins have been widely used as thinner agents in citrus. The mechanisms of action of these substances has been suggested through an increase of the sink capacity of the leaves that, in turn reduce transport of metabolites to the fruit. (Iwaheri, 1978); and their effectiveness is affected by the auxin type, formula, concentration applied and date of treatment (Ortola et al. 1991; August et al. 1996). Nevertheless, significant increases in fruit size occurs only if fruit thinning is higher than $50-60 \%$ of total fruits and if it is performed early in fruit development. It has been shown both manually (Zaragoza et al. 1992) and chemically (August et al. 1995a, 1995b) that it is so that the enhancer effect of synthetic auxins on fruit growth operates via promotion of sink strength.

Applications of synthetic auxins in the citrus industry: Synthetic auxins are widely used as fruit size enhancers in the main countries producing mandarins for fresh consumption: 2, 4, DP and 3, 5, 6 TPA have been shown to have a powerful effect increasing the final fruit size with increments for Clementine mandarins by between $3-4 \mathrm{~mm}$ and 4 $6 \mathrm{~mm}$ in diameter respectively and providing a significant shift of commercial fruit size distribution to the larger sizes. (Agusti et al. 1998).

Fruit characteristics are not modified by their application, except those related to fruit size (i.e peel weight, juice content, e.t.c) that are increase in absolute value; but not in relative value to fruit weight (E1 - Otmani et al. 1993; Agusti et al. 1994).

However, the application of synthetic auxins to increase fruit size often resulted in too erratic results to justify the use of these compounds by the growers (Guardiola and Garcia - Luis, 2000).

The thinning effect of synthetic auxins fruit size enhancement varies depending on the time of application. (Agusti et al. 1995b). Application at the onset of cell enlargement stage increases significantly the final fruit size with no thinning effect (Agusti et al. 1994). When auxin is applied at this stage it stimulates cell expansion, especially of juice vesicles. (El Otmani et al. 1993; Agusti et al. 1955bl Aznar et al. 1995). This cell expansion increases vesicle capacity for juice accumulation and therefore the fruit grows faster. Delaying treatment until cell expansion diminishes or ceases, makes the treatment less effective. (Agusti et al. 1994; Guardiola and Lizoro, 1987).

The activation of cell expansion by auxins requires a maintained cell turgor (Cleland, 1987) which is caused by photosynthesis synthesized actively by the leaves in response to auxin treatment.

Thus, the application of the synthetic auxin 3,5,6, TPA at the cell enlargement stage increases hexoses in developing fruit and although the sucrose concentration also increases, the treatment reduces sucrose / hexose ratio compared with control fruit suggesting that sucrose is more rapidly metabolized in treating developing fruit (Agusti et al. 2002). The result suggest Naphthalein Acetic Acid (NAA) has been the most consistent chemical thinning agent, spray applications of NAA applied about 'June drop' have been effective in reducing crop load, reducing biennial hearing and improving fruit size and quality. (Hilgeman et al., 1964). The effectiveness of NAA for fruit thinning is dependent on factors such as timing of application, concentration, environmental and tree condition as well as cultivar (Wheaton, 1981). Further ,NAA is relatively costly and the development of a cost effective thinning agent is desirable (Maurer and Taylor, 1999).

Other chemicals_which have been applied for citrus thinning are Boron when applied prebloom at concentrations of 2,500-3,00.ppm (Maurer and Taylor 1999), Figaron (Ethyl -5- chrolo - 14-3-indazoly acetate( (Ethylozate) at $400 \mathrm{ppm}$, (Chen and Fu, 1990). 
Lanolin pastes containing $0.02-1.0 \% \mathrm{GA}_{4+7}$ to citrus fruitlets and caused thickening of the peel in the proximity of the treated zone. Enlargement of albedo (white portion of citrus portion of the peel) and the peel were not affected by the hormone.

An exception was the successful use of NAA and in recent times IZAA (S-chloroindazol-8-acetic acid; ethlycholozate) to thin Satsuma mandarins in Japan (Guardiola and Garcia - Luis, 2000).

When NAA was applied at 300ppm sprayed 25 days after full bloom it was found to thin fruit causing a $30 \%$ increase in fruit drop in 1973. The following years, however, the effect of spraying was not significant because the overall percentage of fruit set was low. Cellulase activity of abscission zones of NAA - treated fruit showed considerably increased values in 1973, whereas in 1974 cellulase activity of control and NAA-treated fruit showed similar high values reflecting a higher fruit drop from control trees. (Iwaheri 1976). Yellow, ready - to-abscise fruit from NAA-treated and from control trees produced higher amounts of ethylene than did apparently healthy green fruit from both treated and control trees. NAA caused no leaf abscission nor any increase in cellulase activity in abscission zones. Ethylene production from the leaves also remained low. Spraying 500ppm ethephon (2-choloromethyl phosphoric acid) caused severe leaf fall, markedly increased cellulose activity in abscission zones and ethylene production. (Iwaheri, 1976).

$\mathrm{GA}_{3}$ was slightly less active than $\mathrm{GA}_{4+7}$ cultivars with a naturally thick peel, such as 'Marsh' grape fruit (c. paradises mact) and 'Shamouti' Orange (C. sinensis .L) responded more strongly than thin - peel cultivars (Goldsmidt, 1983).

Hand Thinning: Hand thinning is the manual removal of fruit and is one management tools to reduce crop load to increase fruit size before harvest. It is the most practised and least risky methods of thinning, but very labour intensive, Hand thinning can only become economically viable if there are significantly increases in market returns to offset the costs. Higher value varieties, such as mandarins are often able to achieve economic gain from hand thinning. Some growers have also reported economic gain from hand thinning e.g Navals, especially for the export market. Some growers hand thin to reduce picking and packing costs. Fruit that is significantly small at the end of stage 1 (fruit growth period) (cell division) will probably mature as small, undersized fruit. For some growers especially those who pack their own fruit, it is more economical to pay somebody to pull the small fruit off the tree than to incur the added costs of picking and putting this small fruit though the packing line...(Falivene and Hardy, 2008).

The actual number of good sized fruit that trees can carry is dependent on many factors such as tree age, amount of fruit bearing wood, tree health ,variety and rootstock. Fruit thinning should be done when the frame counts vary from 6-10 or 10-15 depending on variety. (Falivene and Hardy, 2008) .

Timing of Hand thinning: Hand thinning is normally undertaken after natural fruit drop had finished at the beginning of stage II ( Fruit Growth Period) ( cell expansion). Thinning as early as possible will have the most effect on fruit size but thinning slightly later will allow small and scarred fruit to be more easily identified and subsequently removed.

Hand thinning normally commences in late December to early January when fruit size is about $30-40 \mathrm{~mm}$ in diameter. Fruits smaller than $30 \mathrm{~mm}$ are more difficult to locate in the canopy (Falivene and Hardy, 2008) and substantial tree damage from branch breakage occurs. In USA foliar sprays of potassium nitrate have been used top reduce fruit load (Boman, 1997). Late summer topping after bloom reduces fruit load but not yield but increases fruit size due to reduced water stress, reduced leaf area and associated transpiration. This is the mechanism (Stover and Ciliento, 2003).

The single foliar application of $\mathrm{KNO}_{3}$ had no effect on any particular parameter. Several studies have shown increases inn citrus fruit size following foliar application of Potassium, but most studies used multiple applications initiated earlier in the year (Boman 2001, 2002; Boman and Habb, 1998; Swistlik, 1998).

However, single applications were reported to be effective in some grape fruit cultivars (Boman, 1997).

The following methods have been used to reduce crop load in citrus.

\section{- Flower suppression}

This can be undertaken in predicted heavy crop years ("on years") using $\mathrm{GA}_{3}$ at the time of flower initiation in June - July.

\section{- Pruning at Flowering}

Pruning can be undertaken before or during flowering with emphasis on removing weak/dead branches, 
cross over limbs and water shoots. Hedging can also be used during flowering to remove excess flowers, but is non-selective.

- Chemical thinning at (stage 1 Fruit growth) uses Ethephon and it is cost effective in Valencia oranges., Imperial and Murcoh mandarins. The amount of fruit removed depends on temperature and moisture and fruit load and application timing. When crop load are high/heavy $10-15 \mathrm{~mm}$ size of fruits should be removed. (Stover and Ciliento, 2003).

- After the natural fruit drop has occurred, a heavy crop load can be further reduced by hand thinning or light hedging. High hedging will remove fruit on the outside of the canopy. Past studies have reported varying results between chemical and hand thinning treatments. Less percentage of juice (47.2\%) was found to be associated with maximum number of fruits (1400 fruits / tree. Hand thinning treatments having 600 fruits had maximum juice percentage $(50.2 \%)$ as compared to the other hand thinning treatments. This could be due to the production of proportionately more juice in properly developed bigger sized fruits than the smaller. (Miyata, 1999). In growth regulator spray treatment maximum juice percentage $(54.10 \%)$ was found to be associated with NAA (350ppm) where the fruit size was found to be significantly more as compared to all other spray and hand thinning treatment (Miyata, 1999) Jasons and Sharma (1987) reported similar results.

In studies to compare ethephon and hand thinning on citrus fruits the treatments affected yield and quality differently (Sawole et al. 2001). Ten treatments comprising of hand thinning with retention of 600 , $800,1000,1200$, and 1400 fruits (tree and growth regulator treatments i.e NAA $(300,350$, and $400 \mathrm{ppm})$ and Ethephon (200ppm) with control treatment (Water spray). In hand thinning treatment stress with 600 fruits and 800 fruits per tree were found to be at par and these treatments showed significant response in increasing fruit weight over other treatments and control. Similar results were also observed by Knight et al. 1987 in apples, Dhillion et al., 1992), in Grapes and Johnson (1995) in 'Cox' orange Pippin apples.

With respect to peel percentage it was seen that minimum number of fruits on the tree i.e 600 fruits/ tree had minimum peel percentage. In growth regulator spray treatment, minimum peel percentage was observed with the minimum number of fruits on the tree i.e 600 fruits / trees. In growth regulatory spray treatment minimum peel percentage (17.8\%) was found under the 200ppm Ethephon, While maximum was with control $(23.29 \%)$ where fruits were smaller over all other treatments. Brar et al. 1992 reported similar results.

Juice content of fruit was similarly affected with less percentage of juice ( $47.2 \%$ found to be associated with maximum number of fruits (1400 fruits / tree) (Sawale et al. 2001) with hand thinning treatments trees having 600 fruits had maximum juice percentage $(50.2 \%$, as compared to the other hand thinning treatment. This could be explained on the basis of production of proportionately more juice in properly developed bigger size fruits than the smaller one.

Growth regulator spray treatment had maximum juice percentage (54\%) corresponding to NAA (350ppm) where fruits size was more compared to other growth regulator treatments. This agrees with Jason and Sharma (1987) on Mandarin.

There was significant increase in total soluble acids and ascorbic acid content with less acidity in fruit juice of the bigger fruit harvest from trees in hand thinning and growth ,regulator spray treatment. Amongst hand thinning and growth regulator spray treatments, the quality parameters of fruit which were found to be significantly superior with $350 \mathrm{ppm}$ (NAA) were (TSS, 11.80 , Acidity $0.79 \%$ and Ascorbic Acid $55.73 \mathrm{mg} / 00 \mathrm{ml}$ of juice. Sharma and Awasthi (1990) reported similar results in an enriched atmosphere i.e in conditions that increased photosynthesis and sugar availability (Downtown et al. 1987).

Dry Matter Accumulation in Citrus Fruit: The transport of dry matter to developing fruits is driven by their sink capacity. The actual rate of accumulation may be smaller than the potential capacity since it may be limited by assimilate supply and by resistance in, and the capacity of, the path of transport. (Garcia - Luis et al. 2002) Assimilate production in leaves is modulated by the demand for photoassimilates (Goldschmidt and Kuche, 1996; Brucheou and Genard, 1999; Laksio et al., 1999) Thus, to some extent the supply is adjusted to demand by the developing fruits. However, the modulation of photosynthesis by crop load is only significant when crop loads are very low. Changes in fruit load from moderately low to very high has little effect on the photosynthetic rate of leaves. (Goldschmidt and Koch, 1996; Lakso et al., 1999). The availability of photoassimilate is usually 
determined by the avalailability of photoassimilates. However, there is evidence that assimilate supply is a limiting factor in the growth of citrus fruits thus, fruit size is inversely related to fruit number and this has been considered a demonstration of competition between sinks for carbohydrates (Goldschmidts and Monselise, 1977; Guardiola 1988). To support this, it has been reported that both fruit set and initial growth rate increased in Valencia orange trees grown in a $\mathrm{CO}_{2}$. enriched atmosphere i.e in conditions that increased photosynthesis and sugar availability (Downtown et al. 1987)

The capacity of the transport system is not usually regarded as a limiting factor for fruit growth. (Canny, 1973). In a number of fruit tree species namely Citrus (Fishler et al., 1983), deciduous fruit trees (Brocheou and Genard, 1999), the distance to source leaves does not affect fruit growth if not competing sinks are in the path of transport (Garcia- Luis et al. 2001). However, there exists a correlation between pedicel diameter and fruit size at harvest as reported on several Citrus cultivars El-Otmani 1993;Stewart,1952; Bustan et al. 1995). It is important to relate dry matter accumulation in citrus to fruit thinning, more so assimilate partitioning in subsequent studies due to the reports mentioned above.

Effect of crop Density levels on hand thinning: The appropriate crop load is dependant on variety, and growing district. Other factors that need to be taken into account are tree health and age,. Cultural practices and the pruning program, good healthy trees will carry more large fruit than older weaker trees (Hardy et al., 2003). Spacing fruit within a canopy should involve consideration of the amount of crop load supported by a branch. Fruit that is located on strong vigorous branches should be left and be evenly spaced along a branch (Hardy and Falivene, 2008).

Mandarins are sometimes thinned up to three times. The first thinning is undertaken when fruits are about $25-35 \mathrm{~mm}$ in diameter by removing small and blemished fruit and reducing crop load by up to $50 \%$. The second thinning is undertaken 4-6 weeks later, to remove any blemished or sun burnt fruit. A third thinning may be warranted if the desired crop load has not yet been achieved (Hardy et al., 2003).

Hand Thinning methods: The removal of small fruit that will not be of any market value is the key to effective hand thinning. All small, scarred, blemished or deformed fruit should be removed. About 20-30\% of fruitlets should be removed paying close attention to the bottom of tree as higher percentage of small fruit is located in this area. The following should be done.

- Examine the bunches of fruit

- Do not thin out doubles or triples fro the sake of it - because they may grow into a large fruit

- Assess the carrying capacity of the branch and the numbers of surrounding fruit. The bunch may not be thinned if the double or triples are all large in size and are not surrounded by many other fruit.

- For varieties susceptible to sun burn (e.g Mandarins) remove any exposed fruits, especially the tops of trees. (Hardy et al. 2003).

Hand and Chemical Thinning: Some growers use a combination of hand and chemical thinning for very heavy crop loads.

For instance Ethrel is used to reduce fruit numbers when fruits are $10-15 \mathrm{~mm}$ in size, followed by hand thinning to further reduce fruit numbers to the desired level. This techniques can reduce the cost of hand thinning (Falivene and Hardy, 2008).

Excessive cropping is a frequent occurrence in Mandarin and mandarin - like hybrids, resulting in marked alternate bearing and sometimes

Alternate Bearing of Citrus: The severity of alternate bearing varies over time and among Citrus varieties. Alternate bearing occurs more frequently on individual blocks, individual trees within a block, or even on individual branches on a single tree. This phenomena is usually common problem on Pineapple orange and some grape fruit and mandarin varieties (Wheaton, 1986). Alternate bearing is a common problem on Hamlin, and Valencia oranges.

The impact of alternate bearing on fruit size for fresh market fruit is a major factor in profitability. Heavy crops of grape fruit lead to small sizes and misshaped fruit of little commercial value. Heavy crops of mandarin cause delayed maturity, poorer external colour, and small sizes that are unmarketable or are sold only at a reduced price. Fruit size is major factor in the returns of mandarin varieties. Heavy crops of mandarins are also destructive to the health of the tree. Heavy crops loads not only cause limb breakage of Murcott tree, but result in dieback or death of the tree. The loss of leaves and fruit occurs quite suddenly during the fall or winter of one - year crop - and is known as Murcott collapse (Stewart et al. 1968) in Florida, 
USA. This collapse is preceeded by loss of starch from the root system, and may represent excessive carbohydrate and nutrient requirements of the developing fruit. Even in cases where the tree is not killed the damage may be severe enough to severely limit production for 2 years. The stress imposed by excessive crop load also results in a tree more susceptible tree damage.

\section{Application of Fruit Thinning to Manage Alternate bearing: Managing alternate bearing involves increasing production during the off-year, or decreasing crop load during the on- year. The ability to increase yield during the off-year is limited, although some increase the yield in the off-year by girdling branches the previous summer has been reported. (Agusti et al. ,1992). Several possibilities for decreasing yield during the on-year exist. These include hand thinning, chemical thinning, mass removal by mechanical hedging or topping. Hand thinning is expensive and is practiced minimally by citrus growers.}

Chemical thinning is an option to citrus growers but it has not received enough attention. Naphthalein Acetic Acid can be used in citrus fruit thinning. As with all chemical thinning agents, the amount of thinning obtained by application of NAA varies with the condition of the tree and with the environmental conditions. This chemical has potential in improving fruit size and quality. (Wheaton and Stewart, 1973).

Pruning or mechanical removal of fruits is the most common method of reducing crop load in Florida, USA. Mature citrus fruit trees are hedged either every year or every other year to maintain access for equipment and to provide light to the lower portions of the canopy. Trees are usually topped to maintain a height that can be harvested. Topping almost always causes a yield reduction which is undesirable when growing oranges for processing. However, it can be beneficial for fresh fruit groves where fruit size and quality grape fruit and mandarin groves are maintained at a low height by annual topping and produce smaller or moderate crops of high quality fruit. A substantial reduction in yield may occur if trees are kept so smaller, however.

Scheduling topping and hedging operations to reduce crop load during heavy crop years is beneficial. These operations can be timed to be carried out in the early spring before flowering occurs if the certainty of the expected crop load is excessive. The benefits of reducing crop load are more if it carried out earlier in the season (Wheaton, 1986).
To schedule hedging and topping even before the current season's crop load can be estimated as history of alternate bearing is needed.

The factors which determine alternate bearing are fruit size, and maturity for the intended market and the potential for the tree damage from overproduction. However, it has been reported the increase in fruit size from topping does not affect yield increase in large fruit size. Fruit is usually greatest when crop load reduction occurs very early in fruit development (Glenn et al., 1994, Silsby et al 1991) so that the effect of resource enhancement accumulates_over more time. The reports are not comparable to citrus because they are from deciduous fruits which grows over a much shorter period than citrus.

Crop load is much greater in the tops of some citrus trees (Stover et al., 2002b) and topping in such trees might increase the ratio of leaf area per fruit. However Stover and Ciliento, 2003 reported little change in crop load per unit of canopy volume following topping. It has also been reported that chemical thinning increases fruit size more than topping and it also increase return cropping (Stover et al., 2002a).

Due to inconclusive reports from past studies it can be argued that fruit size increase due to topping may depend on the water stress status of the leaves because fruit development is a water requiring process (Stover and Ciliento, 2003). The later workers have reported that the mechanisms of fruit size increases following topping may suggest improvements in other cultural practices to optimize fruit size. If reduced water stress is indeed a primary factor increasing fruit size, it may be appropriate to consider irrigation drainage and canopy crop equilibrium management strategies to improve tree water status in many orchards with small fruit.

More importantly future studies on such fruit thinning practices should compare fruit thinning under varying irrigation frequencies

\section{CONCLUSIONS}

It appears that fruit thinning studies in Citrus has not been as exhausted as in deciduous trees.

Future studies should incorporate the following

- Variation of Photosynthetic rate during the thinning process

- More chemicals should be studied

- More cultural practices should be tested

- Dry matter accumulation and partitioning should be monitored during the thinning process

- More Citrus species and cultural should be incorporated in future studies 


\section{REFERENCES}

Agusti, M, Martinez F, and A Masojo, C (2002) Citrus Fruit Quality, Physiological Basis and Techniques of Improvement. Agrocienca Vol. VI No. 2 pp 1-16

Agusti, M. Almela, V (1991) Appliccion de futoreguladores en citricultura -Ed AEDOS, Barcelona, span.

Agusti, M. El Otmani, M; Aznar, M. Suan, M. Almella, V (1995b) Effects of 3,5,6 Trichloro 2- pyridyloxyacetic acid on Clementine early fruit let development and on fruit size at maturity. J. Hort. Sci. 70; 855-962.

Aznar, M, Almela, V, Juan, M, El Otmani, M and Agusti, M. (1995) Effect of synthentic auxin penothiol on fruit development of 'Fortune' Mandarin .J. Hort .Sci. To 617-621

Bangerth and Quinlan, J. (2000) Editorial Preface. Plant Growth Regulation 31-0-1

Bangerth, F. (2000) Abscission and thinning of young fruit and their regulation by hormones. Plant Growth Regul. 31: 43-59

Banuelos,G.S;Bangerth,F and Marschner(1987) Relationship between polar basipetal auxin transport and acropetal transport in tomato fruit.Plant Physiol.71:321-327

Batjer L;H.D Billingsley,M.N Westwood and B.L Rogers(1957) Predicting harvest size of apples at different times during the growing season Proc.Amer.Hort Scie.70;50-57

Batjer, L.P and M.N. Westwood (1960) I - Naphtthyl Nmethylcarbamate (Sevin) on thinning apples. Amer. Soc. Hort Sci. 77;1-8

Bertschnger L. Stadler W. Krebs, C and Pfammoter (1999) Erhohung der Wirkung SS cher neit Von Ansudungmittern; Er Fahrungen mit Ethephon and ang'e Bter Appli kation stechnik Sweiz, Zeitschnif Obst - Weinban 24; 580-583.

Bramlage,W.J;M.Drake and Bake,J.H(1974) Relationship between $\mathrm{Ca}$ content to respiration and postharvest condition of apples.J.Amer.Soc.Hort.Sci.99 (4) 376378

Brochan, C, Genard M. (1999) A space time model of carbon translocation along a shoot bearing fruits. Annals of Botany $84 ; 565-576$

Bustan A. Erner, Y, Goldschmidt E.E (1995) Interactions between developing citrus fruits and their supportive vascular system,. Annals of Botany 76; 657-666

Bustan A. Ernier, Y, Goldschmidt E.E (1995) Interactions between developing citrus fruits and thier supportive vascular systems. Annals of Botany 76;657-666.

Byers ,R.E,C.G Lyons,Jr and R.I.Horsburg(1982) Comparisons of Sevin and Vyadate for thinning apples HortScience 17:777-778
Byers RE and G. Lyons Jr (1983) Chemical peach thinning and possible sites of action if dessicoting chemicals $\mathrm{J}$. Amer. Soc. Hort. Sci. 110; 662-667

Byers, R.,C.G Lyons, Jr:S.Yoder J.A.B. Arden and R.W Young( 1985) Peach and Apple thinning by shading and photosynthetic inhibition J.Hort.Scie.60:465-472

Byers,R.J Barden and D.Carbaugh( 1990) Apple Thinning by photosynthetic Inhibition.J.Amer.Soc.Hort.Scie.115 (1):14-19

Canny MJ (1973) Phloem Translocation London; Cambridge Univ. Press

Cohen, A. (1984) citrus fruit enlargement by means of summer girdling. J. Hort. Sci. 59; 119-125.

Curry,E.A and M.W Williams( 1987) Enhancing typiness of Delicious apples with substituted pheny ureas. HortScience;5 (22)1143

Denne, M.P (1963a) Fruit development and some tree factor affecting it. N.ZJ Bot. 1;265-296.

Denne, M.P (1963b) A comparison between fruits of Cox's Orange Pippin from Kent, England, Newzealand J. Bot 1:295-300.

Down town WJS Grant WJR, Loveys B.R. (1987) Carbon dioxide enrichment increase yield of valencia orange, Australian journal of Plant Physiology 14; 493-50)

El - Otmani, M.; Cogfins, C.W. Jr, Agusti, M. lovatt, C.L (2000) plant Growth regulations in citriculture; World current uses. Crit. Rev. Plant Sci. 14; 367-412

El Otmani, M, Agusti, M. Aznar M. Almela V. (1993) Improving the size of' Fortune' 'Mandarin fruits by the auxin 2,4, DP. Scientia Hort. 55; 283-290

El Otmani, M; Agusti, M; Aznar M; Almela, V.(1993) Improving the size of' Fortune' Mandarin fruits by the auxin 2,4 DP. $14 ; 367-412$

Elfving,D.C and R.A Cline(1993) BA and other chemicals for thinning 'Empire'apple trees.J.Amer.Soc.Hort.Sci.118:593-598

Esau,K( 1976) Anatomy of seed Plants.

Falivane S. and Hardy, S (2008) Hand Thinning Citrus. New South Wales Department of Primary Industries. Prime FACT 789

Farley, A.J. (1923) Factors that influence the effectiveness of peach thinning. Proc. Amer. Soc. Hort. Sci. 20; 145151.

Faust,M and C.B Shear( 1972) The effect of $\mathrm{Ca}$ on respiration of apples.J.Amer.Soc.Hort.Sci.97:437-439

Faust,M.(1986b) Interaction between nutrient uptake and photosynthesis

in:Atkinson,D,Jackson,J.E,Sharples,R.O and 
Walker,W.M(Eds.) Mineral Nutrition of fruit trees.Butterworth,London 193-200

Faust,M.and A,N Miller(1989) Effect of bioregulators and herbicides on $\mathrm{Ca}$ and $\mathrm{P}$ content of fruits.Acta Horticulturae 239 pp 409-414

Feree,D.C and Palmer,J.W( 1982)Effect of spur defoliation and ringing during bloom on fruiting, fruit mineral and net photosynthesis.of 'Golden Delicious.' Apple J.Amer.Soc.Hort.Sci.107:1182-1185

Fishler, M. Goldschmidt E.E. Monselise S.P. (1983) Leaf area and fruit size. Journal of American society for Horticultural science 108; 218-221.

Freed V.H and Montgomery( 1958) The effect of surfactants on foliar absorption of 3-aminol,2,4triazole. Weeds 6:386-389

Frucht and Triebwachstum Schwiz Zeitschr obs und Wanbau 129; 421-420.

Garcia - Luis M.F M. Oliveira, Y. Bordon, D.L. Siqueira, Forminage S and J.L Guardioala (2002) Dry matter Accumulation in Citrus Fruit is Not Limited by Transport capacity of the pedicel .Annals of Botany 90; 755-764

Goldschmidt E.E (1996) Citrus. In Zamski E, Schaeffer A.A eds. Photoassimilate distribution in plants and crops. New York; Marcel Dekkn Inc 797-823.

Goldschmidt, E.E (1983) Asymmetric growth of citrus fruit peel Induced by localized application of GA3 in Lanolin pastes .Scientia Horticulturae Vol 21, No.2 pp 29-35

Goldschmidt, E.E. Monselise SP (1977) Physiological Assumption toward development of a citrus fruiting model., Proc. International society of Citriculture 2; 381-394.

Gore, R. (1990) Anatomical, Physiological and Hormonal Aspects in citrus .Hort Reviews. J. Janick (ed)

Gore, $R$ ( 1993)Anatomical,Physiological and Hormonal Aspects of Abscission in Citrus In Hort Reviews ,J,Janick(ed.)

Greene ,D.W(1989) Regulation of fruit set in the fruit with plant growth regulators. Acta Horticulturae 239:323-334

Greene ,D.W;W.R Autio and P.Miller(1990) Thinning activity of BA on several apple cultivars.J.Amer.Soc.Hort.Sci.115:394-400

Greene,D.W and W.R Autio(1989) Evaluation of BA as a chemical thinner in 'Mclntosh' apples.J.Amer.Soc.Hort.Sci.114:68-73

Marini,R.P( 1996) Chemically thinning spur Delicoius apples with carbaryl,NAA and Ethephon at various stages of fruit development.HortTechnology 6 (3) :241246
Greene,D.W(1989) Regulation of fruit set in the fruits with plant growth regulators. Acta Horticulturae 239:593-598

Guardiola , JL, Lozoro, E (1987) The effect of synthetic on fruit growth and anatomical development in Sastuma mandarin. Scientia Hort. 31:119-130.

Guardiola, J.L and Carcia - Luis . A. (2000) Increasing fruit size in citrus. Thinning and stimulation of fruit growth .Plant Growth Regul. 31; 121-132

Hands check, M. (1994) Ausdunnung Vol II APfelbaumen mit Kozentrieten Dungern Obstbau 4: 178-181.

Harley,C.P,H.H Moon and L.O Regeimbal(1957) Effects of the additive Tween 20 and relatively low temperatures on apple thinning by Naphthalein Acetic Acid sprays Proc.Amer. Soc.Hort. Sci. 69:21-27

Havis A.L (1992) Effect of time of fruit $t$ hinning of ' Red Haven' Peach Proc. Amer. Soc. Hort Sci. 80: 172-176.

Heinecke,A.J(1964) The microclimate of fruit trees III the effect of tree size on light penetration and leaf area in red Delicious apple trees.Proc.Amer.Soc.Hort.Sci 85:33-41

Hilgeman R.H., L. Time and J.A Dunlop (1964) Effect of NAA and hand thinning on size of Kinnow and Mandarin fruit in Arizona. Proc. Az. State Hort,. Soc. $77 ; 84-87$

Hull,J.Jr;M.J Bukovac and Black,B.C(1995) Effect of concentration and time of Accel application on cropping of selected cultivars.HortScience 30 (4) 765

Iwaheri, S. (1978) use of Growth Regulation in the control of cropping of Mandarin varieties Proc. Intl. Soc. Citriculture.

Janick, J. (1979) Horticultural Reviews Avi. Publishing.

Janick,J.(1979) Horticultural Reviews ,Avi Publishing

Karim, M.R G.C. Wright and K.C Taylor (1996) Effect of Foliar boron sprays on yield and fruit quality of citrus 1996 citrus Research Report. University of Arizona, College of Agriculture, Tucson, AZ, Series, p 105.

Knight,J.N( 1987) Timing of application of carbaryl used as an apple fruitlet thinner.J.Hort.Sci.62;:11-16

Laksco A. N Winsche JN, Palmer JW, Corelli Grappadelli. L. (1999) Measurement and modeling of carbon balance of the apple tree. HortScience. 34;1040-1047

Letham, D.S. (1958) Cultivation of apple fruit tissue In vivo. Nature 182; 473-479.

Marcelle,R.D(1995) Mineral nutrition and fruit quality.Acta Horticulturae

383:219-225

Maurer M.A. and Yatlor, KJ.C. (1999) Evaluation of thinning agents for 'Kinnow Mandarins University of Arizona College of Agriculture Citrus Research Report (http:// ag. Arizona edu /pubs/crops/az 1138. 
Ortola, A.G. Monern, C., Guardiola, J.L (1991) The use of Naphthalein Acetic Acid as a fruit growth enhancer in Satsuma Mandarin; A comparison with the fruit thinning effect. Scientia Hort 47; 15-25

Osborne J.L and Robinson,T(2008)Chemical Peach Thinning;Understanding the relationship between crop load and crop value .New York Fruit Quarterly No.4 Vol.14

Ouma, G (1996) Chemical thinning studies of a Apple Ph.D Dissertation Mississippi State University

Ouma, G. (2010) Flowering, Pollination and fruit set in fruit trees. Lambart Academic Publisher Berlin, Germany 138pp.

Quinlan,J.D and A.P Preston(1971)The Influence of shoot competition on fruit retention and cropping of Apple trees.J.Hort.Science 46:525-534

Schneider, G.W. (1978) Abscission mechanism studies with apple fruit lets. Amer. J. Hort. Sci 103; 455-458.

Schneider,G.W and A.M Lasheen(1973)NAA and Sevin on composition, development and abscission of Apple fruit HortScience 8:103-104

Schonherr J. Bauer P, and Uhlig, B (2000) Rates of cuticular penetration of 1-Naphthyl acetic acid (NAA) as affected by adjurants, temperature, humidity and water quality. Plant Growth Regulation 31; 61-74

Schumacher, R. Neuweiler R, ad Stadler, W. (1993) Einflub der fruchtansdudung auf Fruchtsansatz und Triebwachstum Schwiz Zeittschur obs und Weibau 129:421-426

Schumacher, R; Neuweiler, R and Stadler W (1993) Einflub der Fruch Tausdudung auf Fruchten satz, Frucht and Triebwachstum schwitzs Zeitchr Cbst. Und. Wein bau $129 ; 421-426$.

Sharma R.K and Awasthi R.P (1990) Indian J. Hort. 47I 162-166

Shoemaker, J.S (1933) Certain advantages of early thinning of Elberta Peaches. Proc. Amer. Soc Hort Sc. $30 ; 223-229$

Smith, A.R and Hall. M.A (1993) Mechanism of ethylene action. Plant Growth Regulation 2; 151-165

Stewart WS, Hield HZ, Brannaman, VL (1952) Effects of 2,4-D and related substances in Furit drop, yield, size and quality of Valencia Oranges Hilgardia 21; 301 . 309.

Stopar, M, Black, B.L and Bukovac M.J. (1997) The effect of NAA and BA on $\mathrm{C} 02$ assimilation by shoot leaves of spur type 'Delicious' and Empire apple trees. J. Amer. Soc. Hort. Soc - 122;837-840,

Stover, E and S. Ciliento (2003) Late summer Topping, Increase Fruit size in Indian River 'Murcott' with Little Reduction in yield Proc. Fla. State Hort. Soc. 116;
2003 Gallasch, P.T. (1988) Chemical thinning of heavy crops of Mandarins to increase fruit size. Proc. $6^{\text {th }}$ Inter. Citrus Confr. 11395 - 405

Teubner, F.G. and A.E Murueck (1955) Embryo abortion as mechanisms of hormone thinning of fruit MO. Afr. Expt Stat Res. Bul 590 Columbia.

Teubner, F.G. and A.E. Muruek (1955) Embryo Abortion as mechanisms of hormone thinning of fruit. Mo Agr. Expt. Stat. Res. Bul. 590 Columbia

Untied, R. and M. Blanke (2001) Effect of fruit thinning agents on apple tree canopy photosynthesis and dark Respiration Plant Growth Regulation 35-1-9

Valenzuela, J.R.C (1992) Regulating blue Berry (V. Ahei) crop Ph.D Dissertation, Mississippi, State Univeristy

Walsh, CJ, HJ. Swartz and L.J Edgerton (1979) Ethylene evolution in apple following postbloom thinning sprays. HortSci. 14;704-700.

Westwood ,M.N and L.P Batjer(1960)Effects of environment and chemical additives on absorption of NAA by apple leaves.Proc. Amer. Soc. Hort. Sci.85:110

Westwood, M.N (1993) Temperate Zone Pomology Timber Press

Wheaton, T.A (1986) Alternate bearing In. Citrus flowering, fruit set and development. Univ. Fla. Citrus short course. pp 67-72

Wheaton, T.A and I. Stewart (1973) Fruit thinning of tangerines with Naphthalein Acetic Acid. Proc. Soc. $86 ; 48-52$

Wheaton. T.A (1981) Fruit thinning of Florida Mandarins using Plant Growth regulator. Proc. Intl. Soc. Citriculture 1981; 263-208.

Williams M. (1979) Chemical fruit thinning in J. Janick (ed.) Hort. Reviews Vol. 1 Avi. Publishing Co. Inc.

Williams,M.W(1993) Comparison of NAA and carbaryl petal-fall sprays on fruit set of apples.HortTechnology :3 (4):428-429

Zaragoza, S Alonso E (1975) Eil Manchodo dela cortesa de los agrios. Estudio preliminor en la Commun INA,Serv Prot.Veg.4 5-8,13-14,19-22,31-32

Zaragoza, S, Tenor, I. Alonso, E Primo Millo, E. Agusti, M (1992) Treatments to increase the final fruit size an Satsuma clauselline Proc. Int. Soc. Citriculture, 2; 725728.

Zimmer, J. and Handchack . M. (1996) Blute nousdung mit Kozentrierten Dungern Obstbau 4; 178-181

Zucconi,I.(1983) Handbook of Fruitset and development CRC Press,Boca,Raton,Fla pp303-332 